\title{
TAXATION OF EMPLOYEES IN ROMANIA IN 2018. CHANGES AND ITS RESULTS ON THE COUNTRY'S ECONOMY
}

\author{
Andrei lonuț Hușman \\ Bucharest University of Economic Studies, Bucharest, Romania \\ husman.andrei@yahoo.com
}

\begin{abstract}
The politico-economic context has a significant influence on the development of a country and the visions of the decision-makers together with the economic policies implemented are key elements in a country's economic welfare. A decisive aspect of the economic policy is the fiscal framework, and when it is not at least stable, the entire economy suffers. In the recent period, in Romania, there have been various tax changes. The present paper analyses perhaps the most controversial tax change, namely, the shifting of social security contributions from the employer's burden to the employee, along with the reduction of their rate and the reduction of the income tax rate. Implementation of such measures should be examined in terms of economic impact. One can notice that these changes have impact on three stakeholder categories: employees, employers and the state budget. Moreover, these changes must be correlated with other measures that are not directly related to the fiscal framework. At the same time, seeing an overview, one can analyze whether these changes could actually represent a starting point for moving from proportional taxation to progressive taxation. Through several impact assessments, this paper aims to analyze both from a micro and macroeconomic perspectives this tax changes and to offer a clear overview of the economic issues arisen. Such analyses will demonstrate the economic instability created through these measures.
\end{abstract}

Keywords: taxation, employees, employers, income tax, social contributions, tax burden

JEL classification: $\mathrm{H} 30, \mathrm{H} 20, \mathrm{~K} 34$

\section{Introduction}

Since the 1990s, Romania has undergone various "experiments" in fiscal terms (and not only). Being a post-communist era, the country needed time to adapt to the conditions and the implications of a market (capitalist) economy, and furthermore, it needed time to adapt to democracy.

Further, after joining the European Union ("EU") in 2007, another series of changes took place in Romania due to the need to adapt to EU legislation. Inevitably, the changes also focused on the fiscal field, local tax legislation aligning with the EU requirements, both in terms of direct and indirect taxation.

After this wave of changes, it seemed that Romania's fiscal policy had reached a certain point of stability. Nevertheless, lately, with many changes in the state governance, there have been a series of major tax changes due to different views and concepts of decision-makers as regards the fiscal policy.

Given the multitude of changes, the economic environment in Romania faces these times a critical level of uncertainty. Lack of coherence and non-compliance with fiscal principles inevitably lead to flawed governance. All the legislative changes must be followed by robust economic impact analyses.

The most important change implemented is the shifting of social security contributions from the employer's burden to the employee, a measure that has not been followed by an impact assessment. Such analyses should focus on the impact on employees, employers, but also 
on public finances. At the same time, these measures can also have an effect on tax avoidance, or even worse, on tax evasion.

Prior to the actual analyses of these measures, we should look at some aspects of public finance and fiscal policy.

\section{Considerations on budgetary and fiscal policies. Literature review}

Being a concept composed of a plurality of factors, public finances are understood and defined in various ways.

Văcărel (2007) provides a classic definition of public finances. As such, he ascertains that public finances represent a tool allowing the control of public financial resources and, at the same time, public finances reflect the objectives of the state's financial policy.

Since the public finances are controlled through budgetary and fiscal policies, it is understandable that the tax system (managed by fiscal policy) is a defining element in the economic evolution of a country.

As regards the tax systems, it can also be perceived in many ways. A reliable definition is offered by Cioponea (2007) which defines the tax system as:

"the expression of the political will of an organized human community, established in a determined territory and having sufficient autonomy to be able, through the organs it represents, to acquire a whole series of legal and, in particular, tax rules". (Cioponea, 2007)

The importance of budgetary and fiscal policies in defining the economy evolution is a subject of interest for many authors. Some of them are Dronca and Arjocu, who, besides the importance, demonstrate the role of these two policies in ensuring a level of development for citizens (Dronca and Arjocu, 2015).

Despite the fact that Romania is an EU Member State, this does not require the implementation of a default system of taxation; in fact, each Member State have the freedom to build its own tax system, but taking into account EU tax regulations, regulations that are seen more like guidelines and do not require the implementation of a specific tax system. In order to support these facts, we can bring Šimović's arguments, who noticed that the fiscal system in the EU reflects the level of separation between economic integration reinforced by the existence of the single market and the creation of a stronger political union (Šimović, 2007).

Taxation of individuals and its effects on the economic environment, the efficiency of tax systems in terms of tax equity and the tax burden represent important topics for many researchers.

Thus, by analysing the distribution of fiscal effort in the case of Portuguese individuals and aiming at demonstrating that the distribution of tax burden is not fair and does not correspond to the declared income level, Catarino and Soares (2017) obtained results that show the lack of harmony between the theoretical idea of established justice and the tax effort of various income groups analysed.

By developing a model of personal income tax ("PIT"), Vlachy (2008) analyses the fiscal changes in the Czech Republic (in the sense of lowering the tax on individuals) coming into effect from 2008, as the entire Czech tax system went through major restructuring. Therefore, the author shows that in the previous tax system, starting from low income, the marginal tax rate was zero, followed by a sharp increase and then by a gradual rise to the thresholds of high income. And, as a result of the reform, the situation is significantly changed, in the sense that the growth is much more gradual, reaching its maximum at the level of the medium income and decreasing towards the high income.

Through their research, Nwanyanwu and Ofiafoh (2016) demonstrated that the Nigerian PIT 
is not productive due to the lack of equity. Analysing the fiscal policy in the Albanian economy during the transition period (after 1990), Nurja (2016) found that PIT underwent many changes almost at every 2.8 years and that there is a strong link between PIT and GDP dynamics. At the same time, the author notes that the frequent change of the PIT rate is not advisable, since such frequent changes have a negative impact on the revenue collection performance.

In his research on social security contributions ("SSC") systems, Fehr (2016) found that a progressive structure having at least some flat benefit might be optimal for providing intergenerational risk sharing. Furthermore, the research on SSC in the case of Germany conducted by Nuemann (2017) found that the SSC burden is equally shared between employees and employers in Germany and that the employment response to SSC capping is negligible.

Following the awareness of the importance of healthy fiscal and budgetary policies, below are presented the measures subject to this paper.

\section{Measures implemented}

In the second half of 2017 there were countless discussions in the media regarding the changes in terms of taxation of employees. The decision-makers performed these changes in a fast-forward manner. Firstly, the discussions were materialized in a draft normative act, and then, in November, it was published in the Official Gazette the Government Emergency Ordinance no. 79/2017 for amending and completing the Law no. 227 on Fiscal Code (the "Ordinance").

This Ordinance provides a lot of legislative amendments, but the most important and those related to this paper provide:

- the shifting of the pension contributions and health fund contribution in full to employees* $^{*}$ (the "transfer") - It remained on the employer's burden the pension contribution at a rate of $4 \% / 8 \%$ for uncommon/special work conditions;

- the reduction of their rate from approx. $39.25 \%$ to $35 \%$;

- the reduction of the income tax rate from $16 \%$ to $10 \%$;

- the introduction of the insurance contribution for work at a rate of $2.25 \%$ under the employer's burden;

- the increase of the amount of personal deductions and the threshold applicable (we will refer to all as "the changes").

These measures are applicable starting with $1^{\text {st }}$ of January 2018.

Besides the above changes, the following amendments should be mentioned:

- the increase of the minimum gross salary from $1,450 \mathrm{RON}$ to $1,900 \mathrm{RON}$ as of $1^{\mathrm{st}}$ of January 2018 (established by the Government Decision no. 846/2017 for establishment of the minimum gross national salary guaranteed in payment);

- establishing the gross average salary used to substantiate the social security budget for 2018 at 4,162 RON (through Law no. 3/2018 on the social security budget for 2018);

- fiscal loosening measures for freelancers and broadening the types of activities for micro-enterprises (through the Ordinance);

- designing the state budget for 2018 on the basis of an economic growth of $5.5 \%$ and a budget deficit of $2.97 \%$ of GDP (through the Law no. 2/2018 on the state budget for 2018).

For a more efficient and reliable results, these changes need to be analysed together. 


\section{Effects on the economic environment}

This chapter presents the implications of the changes on the Romanian economy, with preponderance over the employees, employers and the state budget/public finances.

All the computations performed in this chapter are based on the assumption that the employees have no dependents and without taking into account any meal tickets receivable by the employees.

\subsection{General impact on employees and employers}

The following analyses offer an overview of the implications of the changes in terms of implications at both employees and employers level, by comparing the old system of taxation with the new one entered into force starting $1^{\text {st }}$ of January 2018.

In performing the analyses, we have taken into account the new minimum gross salary of $1,900 \mathrm{RON}$, the average gross salary registered in November 2017 of 3,430 RON (last one available) according to the Ministry of Labour and National Institute of Statistics and the average gross salary established by the social security contribution legislation for 2018 of 4,162 RON.

Table 1: Salary taxation in 2017

\begin{tabular}{|c|c|c|c|c|c|}
\hline \multicolumn{2}{|c|}{ Item } & Rate & \multicolumn{3}{|c|}{ Amount (RON) } \\
\hline \multicolumn{3}{|l|}{ Gross salary } & 1,900 & 3,430 & 4,162 \\
\hline \multicolumn{2}{|l|}{ Income tax } & $16 \%$ & 218 & 458 & 556 \\
\hline \multirow{3}{*}{$\begin{array}{l}\text { Employee's } \\
\text { contributions }\end{array}$} & Pension contribution & $10.50 \%$ & 200 & 360 & 437 \\
\hline & Health insurance fund & $5.50 \%$ & 105 & 189 & 229 \\
\hline & Unemployment insurance fund & $0.50 \%$ & 10 & 17 & 21 \\
\hline \multicolumn{3}{|c|}{ Personal deduction } & 220 & 0 & 0 \\
\hline \multicolumn{3}{|c|}{ Net salary } & 1,367 & 2,406 & 2,919 \\
\hline \multicolumn{3}{|c|}{ Effective tax rate (\%) } & 28.05 & 29.85 & 29.87 \\
\hline \multirow{6}{*}{$\begin{array}{l}\text { Employer's } \\
\text { contributions }\end{array}$} & Pension contribution & $15.80 \%$ & 300 & 542 & 658 \\
\hline & Health insurance fund & $5.20 \%$ & 99 & 178 & 216 \\
\hline & Unemployment insurance fund & $0.50 \%$ & 10 & 17 & 21 \\
\hline & Medical leave fund & $0.85 \%$ & 16 & 29 & 35 \\
\hline & Guarantee Fund & $0.25 \%$ & 5 & 9 & 10 \\
\hline & $\begin{array}{l}\text { Work accidents, risk insurance } \\
\text { and occupational disease fund }\end{array}$ & $0.18 \%$ & 3 & 6 & 7 \\
\hline \multicolumn{3}{|c|}{ Total employer's cost } & 2,333 & 4,211 & 5,109 \\
\hline
\end{tabular}

Source: own calculations and data processing based on Romanian legislation

In order to be able to carry out a comparative analysis, table 1 presents the situation of the taxation methodology applied in 2017 based on the three salary levels mentioned above.

At a first glance, one can notice the difference in the effective tax rate of 1.80 percentage points ("pp."), respectively $1.82 \mathrm{pp}$. between the minimum salary and the two average salaries. The difference is caused by the personal deduction applied for the minimum salary. Regarding this personal deduction, we will notice in the following chapters that it has a rather significant impact on the taxation of salaries.

The methodology used in 2017 implied a so-called solidarity from the employer, in the sense that both, the employee and the employer, were contributors to the social security budget. 
Table 2: Salary taxation in 2018 (keeping the same net amount)

\begin{tabular}{|c|c|c|c|c|c|}
\hline \multicolumn{2}{|c|}{ Item } & Rate & \multicolumn{3}{|c|}{ Amount (RON) } \\
\hline \multicolumn{3}{|l|}{ Gross salary } & 2,250 & 4,112 & 4,990 \\
\hline \multicolumn{2}{|l|}{ Income tax } & $10 \%$ & 95 & 267 & 324 \\
\hline \multirow{2}{*}{ Employee's contributions } & Pension contribution & $25 \%$ & 563 & 1,028 & 1,248 \\
\hline & Health insurance fund & $10 \%$ & 225 & 411 & 499 \\
\hline \multicolumn{3}{|l|}{ Personal allowance } & 510 & 0 & 0 \\
\hline \multirow{2}{*}{\multicolumn{3}{|c|}{$\begin{array}{l}\text { Net salary } \\
\text { Effective tax rate (\%) }\end{array}$}} & 1,367 & 2,406 & 2,919 \\
\hline & & & 39.24 & 41.49 & 41.50 \\
\hline Employer's contributions & Work insurance contribution & $2.25 \%$ & 51 & 93 & 112 \\
\hline \multicolumn{3}{|l|}{ Total employer's cost } & 2,301 & 4,205 & 5,102 \\
\hline
\end{tabular}

Source: own calculations and data processing based on Romanian legislation

Table 2 presents the most probable situation in the economic reality, starting from the hypothesis that an honest employer keeps the same net salary for its employees.

This case, where the net salary is constant, represents a slight advantage for employer, as its total costs slowly decrease.

However, at the employer's level there is an impact of raising the minimum gross salary to $1,900 \mathrm{RON}$ on the disability fund contribution paid by the employer.

The disability fund is a contribution per company calculated to the minimum gross salary multiplied by the number of jobs that the company did not employ persons with disabilities (it is not calculated individually and it is not part of the contributions mentioned in the Fiscal Code). Each company having at least 50 employees and that does not hire at least $4 \%$ of the total number of employees persons with disabilities, is obligated to pay this contribution that is used by the state to protect this social category.

If by September 2017, this contribution was calculated at $50 \%$ of the minimum gross salary, and companies also had the option of purchasing products or services made through their own activities of persons with disabilities employed within the authorized protected units, in the amount equivalent to the amount due to the state budget, after this month the contribution is calculated at $100 \%$ of the minimum gross salary and the option mentioned is no longer available.

It can be noticed that in the cases of companies that cannot employ persons with disabilities due to the specific of their activities, the possible savings from the transfer of contributions to employees will be offset by the additional amount to be paid to the disability fund. In some cases, savings will not cover this amount.

Thus, even if at first sight the employer benefits from an advantage in the presented scenario, its financial situation may be affected also indirectly by the increase of the minimum gross salary. 
Table 3: Salary taxation in 2018 (keeping the same gross salary/employer's costs)

\begin{tabular}{|c|c|c|c|c|c|c|c|c|}
\hline \multicolumn{2}{|c|}{ Item } & \multirow{2}{*}{ Rate } & \multicolumn{3}{|c|}{$\begin{array}{c}\text { Scenario }{ }^{*} \\
\text { Amount (RON) }\end{array}$} & \multicolumn{3}{|c|}{$\begin{array}{c}\text { Scenario 2**} \\
\text { Amount (RON) }\end{array}$} \\
\hline \multicolumn{2}{|l|}{ Gross salary } & & 1,900 & 3.430 & 4.162 & 2282 & 4.118 & 4.997 \\
\hline \multicolumn{2}{|l|}{ Income tax } & $10 \%$ & 73 & 217 & 271 & 97 & 268 & 325 \\
\hline \multirow{2}{*}{$\begin{array}{l}\text { Employee's } \\
\text { contributions }\end{array}$} & $\begin{array}{l}\text { Pension } \\
\text { contribution }\end{array}$ & $25 \%$ & 475 & 858 & 1041 & 571 & 1030 & 1249 \\
\hline & $\begin{array}{l}\text { Health } \\
\text { insurance fund }\end{array}$ & $10 \%$ & 190 & 343 & 416 & 228 & 412 & 500 \\
\hline \multicolumn{3}{|c|}{ Personal allowance } & 510 & 60 & 0 & 510 & 0 & 0 \\
\hline \multicolumn{3}{|l|}{ Net salary } & 1,162 & 2,012 & 2,434 & 1,386 & 2,408 & 2,923 \\
\hline \multicolumn{3}{|c|}{ Effective tax rate (\%) } & 38.84 & 41.34 & 41.52 & 39.26 & 41.53 & 41.50 \\
\hline $\begin{array}{l}\text { Employer's } \\
\text { contributions }\end{array}$ & $\begin{array}{l}\text { Work } \\
\text { insurance } \\
\text { contribution }\end{array}$ & $2.25 \%$ & 43 & 77 & 94 & 51 & 93 & 112 \\
\hline \multicolumn{3}{|c|}{ Total employer's cost } & 1,943 & 3,507 & 4,256 & 2,333 & 4,211 & 5,109 \\
\hline
\end{tabular}

${ }^{*}$ Scenario 1: keeping the same gross salary amount

${ }^{* *}$ Scenario 2: keeping the same total employer's costs

Source: own calculations and data processing based on Romanian legislation

In table 3 are presented the "extreme" scenarios, namely keeping the same gross salary amount for the employee and keeping the same total costs for the employers.

Given the constant migration of employees and the growing need for companies to have a stable workforce, the situation where the employer keeps the same gross salary for the employee is less probable in a competitive labor market, and we do not anticipate many such cases. Even though, this scenario should not be overlooked, since it leaves room for abuses by certain employers.

A win-win situation is observed in scenario 2, where the employer keeps the costs with its employee at the level of 2017, and the latter records a slight increase in net salary.

As can be seen from table 2, the main effects of the changes are the increase in the employee's fiscal pressure of over 10 pp., as well as a major fiscal loosening at the level of the employer. However, at the one hand, as mentioned above, some employers may still be affected by the increase of the contribution to disability fund and, on the other hand, some employers may be affected by the increase of the threshold for framing as micro-enterprise. Thus, the changes can not translate as a fiscal loosening for all companies.

As a side note, according to an analysis of Ziarul Financiar, only approx. $30 \%$ of the employees in Romania recorded in 2016 a salary above the average (Ziarul Financiar, 2016). Given the economic growth registered in 2017 the proportion has definitely changed, in the sense that the salaries increased (no updated data has been found) - the average gross salary also increased during this period.

Nevertheless, judging in general terms, we can anticipate that more than $30 \%$ of the Romanian employees will register a fiscal pressure of over $40 \%$. The fact that the other percent of employees will register a lower fiscal pressure is due to the personal deduction. In this respect, we have performed other analysis in the following chapter.

\subsection{Effective tax rates. Premises for eventual progressive taxation}

In figure 1 below, we compared the trend of effective tax rates registered for 2017 with that of 2018. In highlighting these situations, we have started from the new salary intervals for which employees benefit from a personal deduction, and for the comparative analysis we have adapted them to the legislation applicable in 2017. The purpose of this analysis is to observe the difference in taxation of employees created by the introduction of those measures. 


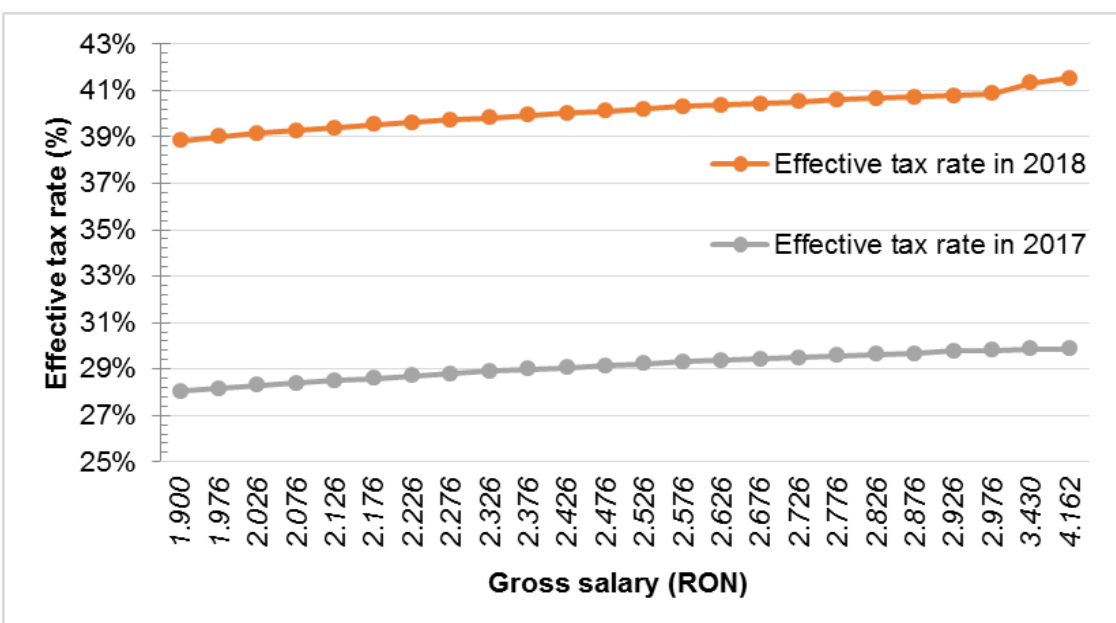

Figure 1: Trend of effective tax rates in 2018 vs. 2017

Source: own calculations and data processing based on Romanian legislation

As can be seen from the figure above, in 2018 the trend of increasing the effective tax rate based on the established salary thresholds is more pronounced compared to 2017. If in 2017 the average rate of increase of the fiscal pressure was 1.81\%, in 2018 the average rate rises to $2.68 \%$. At the same time, there is a more pronounced difference in 2018 compared to 2017 from the salary threshold of 2,976 RON to 4,162 RON in terms of fiscal pressure.

The analysis stops at the salary threshold of 4,162 RON, since above this threshold the effective tax rate remains constant, due to the fact that there is no personal deduction applicable. Corroborating this with the measure from the beginning of 2017 that eliminated the capping of the two contributions (pension and health fund contributions) to the maximum of 5 average gross salaries, one can see the more intense impact on the middle-class, which will bear a very high pressure.

Taking into account the increase of the income ceiling of the persons who can fit into the category of dependents, as well as the effective income of the deductions, combined with a high fiscal pressure of the middle class, we can highlight the socialist character of the economy policy implemented.

Furthermore, seeing this more pronounced approach of taxing the income on a threshold basis, one can argue that all these measures might create the environment for the transition to a progressive taxation. As a consequence, a progressive taxation may create some budgetary instability, especially given that Romania's economy is emerging. At the same time, an advantage of this taxation may be the creation of some social equity.

\subsection{Considerations regarding the tax avoidance/tax evasion}

The Fundamental Notice of the Ordinance shows that the introduction of the measures subject to this paper is also due to the need of increasing the level of social contributions collection by the state and to empower employers to pay in due time the mandatory social contributions.

But, since the social contributions are still withheld and paid by the employers on behalf of employees (as well as up to this change, but in other proportions), these amendments do not solve this problem, as they do not bring any change in the actual payment of contributions. Such problems could be mitigated by increasing the capacity of the tax authorities to collect and to perform effective controls on bad debtors.

Moreover, due to other amendments, the fiscal pressure at a freelancer's level is lower than in the case of the employee. Consequently, some of the employees will be tempted to 
choose to carry out their activities as freelancers/self-employed persons. Thus, in most cases, even if "on paper" the freelancer fulfils the conditions of independence mentioned by the tax legislation, in fact he behaves identically with an employee.

Besides those mentioned, given that framing as micro-enterprise is no longer conditioned by the specific of the activity (with an emphasis to financial and consultancy activities), employees will also be tempted to carry out their activities as micro-enterprise due to more favourable fiscal conditions, and in reality to behave as an employee.

These facts lead to an increase of the tax avoidance/tax evasion since there are such "alternatives".

\subsection{Impact on public finances/state budget}

In general terms, one can predict the fact that the changes can bring a minus of revenues to the state budget of $6 \mathrm{pp}$. in terms of income tax and $2 \mathrm{pp}$. in terms of social contributions. But, in reality, it is expected that the new rates to be applicable to a higher taxable base.

In analysing the impact of these measures on public finances, it is necessary to mention the Significant Deviation Procedure ("SDP") established by the European Commission (the "Commission") on Romania at the beginning of 2017 as a result of the increase of the structural deficit of Romania in 2016 compared to 2015 by about $40 \%$ reaching $2.5 \%$ of GDP in 2016. This increase is based on the reduction of VAT rate and salaries growth in the public sector.

Following the mission in September 2017, in the related Report, the Commission estimated that the deficit would continue to increase if there are no policy changes in the sense of consolidation measures and stated:

"It was understood that the Romanian authorities do not intend to act upon the SDP recommendation" (European Commission, 2017)

The execution of the state budget for 2017 shows that the state managed to collect the revenues from salary and income tax at the level proposed at the beginning of 2017, and in terms of social security contributions the level was even above the proposed one with approx. 2 billion RON. Thus, we can argue that these two sources were stable and even increased compared to 2016. However, following the recent measures, this stability is no longer necessarily valid.

Regarding a possible decrease of revenues from salary and income tax, we could anticipate that this could be offset by a possible increase in terms of revenues from micro-enterprise tax, since the framing threshold was increased.

Furthermore, despite the fact that the state budget for 2018 was built based on the basis of a relatively high economic growth of $5.5 \%$, the perception in the economic environment is different, many economists being reluctant to this increase. For example, in the report issued by UniCredit economists in January 2018, it is stipulated:

"Economic growth is expected to slow to $4.6 \%$ this year and $3.5 \%$ in 2019 from $6.6 \%$ in 2017 . This could be the direct result of growth relying heavily on consumption and inventories, while investment is crowded out by populist measures or affected by fiscal uncertainty. Growth may slow even more if stealth fiscal tightening is used to keep the budget deficit below 3\% of GDP" (UniCredit Bank, 2018).

Considering the fiscal instability and consumption-based economic growth, it is anticipated that the appetite for consumption will decrease as the population will be reluctant in this respect, the psychological impact of the fiscal changes being significant.

Consequently, the difficulty in stabilizing the state budget will be increasingly higher and compensatory measures such as cutting the budget expenditures or imposing additional taxes are expected. 


\section{Conclusion}

All these fiscal measures have to be viewed as a whole and must be correlated with other measures that do not necessarily concern the fiscal field.

As the main effects, we were able to identify a higher fiscal pressure for employees and the social character of the changes, but also a fiscal loosening at the employers' level, even if in most of the cases such loosening is oppressed by other measures. Moreover, these changes can create the premises for the implementation of a progressive taxation.

As regards the budgetary impact, the measures may lead to instability in terms of budget revenues. Furthermore, budgetary/fiscal uncertainties may lead to a risk for Romania to enter into a conflict with the European Commission.

Overall, we have noticed that the introduction of fiscal/economic measures in a fast-forward manner and without a reliable strategy creates strong instability on the economy.

It is clear that the efficiency of a tax system is represented by the ability of the governors to obtain maximum tax revenues without a high tax pressure on taxpayers. Considering that Romania is an EU member state, we have to look at the EU fiscal environment. In this context, the EU Member States have different visions on designing the PIT systems. However, as per our research, there is no other EU country that currently applies a tax system where the SSC are exclusively on the employees' burden. Furthermore, for example, according to PwC (2017), in terms of SSC, the fiscal system in Estonia provides that the employee contributes only with $1.6 \%$, while employees contribute with $33.8 \%$.

From a bureaucratic point of view, we can notice that the measures subject to this paper bring some simplification in taxation process by reducing the number of SSC.

\section{Acknowledgements}

A brief part of the analyses (at an early stage) of the impact of the transfer of social contributions to the employees was presented during the eight edition of Doctoral Symposium in Economic Studies organized by the Faculty of Economies Studies, University of Oradea, on 23 November 2017. At that moment not all of these amendments were published in the Official Gazette of Romania.

\section{References}

Catarino, J. S., Soares, R. M., 2017. Inequalities on Tax Effort of Personal Income Tax. Sequência (Florianópolis), 76.

Cioponea, M. C., 2007, Finanțe Publice și Teorie Fiscală, Editura Fundaţiei România de Mâine, Bucuresti.

Dronca, A., Arjocu A., 2015, The impact of fiscal and budgetary policies on the unemployment rate in the EU Member States [online]. Annals of the „Constantin Brâncuși” University of Târgu Jiu, Economy Series, 1 (II), pp. 203-207, available at: http://www.utgiiu.ro/revista/ec/pdf/2015-01.Volumul\%202/32 Dronca,\%20Arjocu.pdf,

[accessed 30 January 2018].

European Commission, 2017. Report from the Commission to the Council: Commission report to the Council pursuant to article 11(2) of regulation EC 1466/97 on the enhanced surveillance mission in Romania [online], Brussels, available at https://ec.europa.eu/info/files/commission-report-council-pursuant-article-11-2-regulation-e c-1466-97-enhanced-surveillance-mission-romania en [accessed 22 November 2017

Fehr, H., 2016. CGE modeling social security reforms. Journal of Policy Modeling, 38(3), pp. 475-494.

Government Decision no. 846/2017 for establishment of the minimum gross national salary guaranteed in payment.

Government Emergency Ordinance no. 60/2017 for amending and completing the Law no. 
$448 / 2006$ on the protection and promotion of the rights of persons with disabilities.

Government Emergency Ordinance no. 79/2017 for amending and completing the Law no. $2 / 2018$ on the state budget for 2018 .

Law no. $227 / 2015$ on the Fiscal Code.

Law no. $3 / 2018$ on the social security budget for 2018 .

Law no. 448/2006 on the protection and promotion of the rights of persons with disabilities. Ministry of Labour and Social Justice, 2018. Statistics, last update 30 January 2018, available at http://www.mmuncii.ro//33/index.php/ro/transparenta/statistici/date-statistice [accessed 30 January 2018].

Ministry of Public Finance, 2018. Budgetary executions, last update 30 January 2018, available

http://www.mfinante.ro/pagina.html?pagina=buletin\&categoriebunuri=executie-bugetara,ra poarte-trimestriale, rapoarte-semestriale, rapoarte-anuale, arieratele-unitatiilor-administrativteritoriale [accessed 30 January 2018].

National Institute of Statistics, 2018. Earnings - since 1991, the monthly series, last update 15 January 2018, available at http://www.insse.ro/cms/ro/content/castiguri-salariale-din-1991-serie-lunara [accessed 30 January 2018].

Neumann, M., 2017. Earnings responses to social security contributions. Labour Economics, 49, pp. 55-73.

Nurja, I., 2016. Dynamics and Place of the Personal Income Tax in Albanian Economy. Academic Journal of Interdisciplinary Studies, 5(3), pp. 25-34.

Nwanyanwu, L. A., Ofiafoh, E., 2016. Assessing the Productivity of Personal Income Tax System in Nigeria. Account and Financial Management Journal, 1(7), pp. 493-448.

PwC, 2017. Estonia. Individual - Other taxes [online], available at http://taxsummaries.pwc.com/ID/Estonia-Individual-Other-taxes [accessed 30 January 2018].

Šimović, H., 2007. Fiscal system and fiscal relations in the European Union: political restraints and alternative approach to public finance. Faculty of Economics and Business, University of Zagreb, Working Paper Series, no. 07.04.

UniCredit Bank Romania, 2018. On the cusp. Macroeconomic and Strategic Analysis Quarterly Report [online], 26 January 2018, available at: https://www.unicredit.ro/ro/institutional/Centru-media/Publicatii.html [accessed 30 January 2018].

Văcărel, I., 2007. Finanțe Publice, $6^{\text {th }}$ edition, Editura Didactică şi Pedagogică, Bucurestit. Vlachy, J., 2008. A dynamic model of personal income tax. $E$ a M: Ekonomie a Management, 11(3), pp. 85-93.

Ziarul Financiar, 2016. Pentru prima oară ZF prezintă distribuţia detaliată a salariilor din România. 34.000 de angajaţi câştigă peste 10.000 lei net pe lună. La polul opus, $70 \%$ dintre salariaţi câştigă sub 1.700 de lei lunar, salariul mediu pe economie [online], published on 16 May 2016, available at http://www.zf.ro/eveniment/prima-oara-zf-prezinta-distributia-detaliata-salariilor-romania-3 4-000-angajati-castiga-peste-10-000-lei-net-luna-polul-opus-70-dintre-salariati-castiga-1-7 00-lei-lunar-salariul-mediu-economie-15284575 [accessed 21 November 2017].

\section{Bio-note}

Andrei Hușman is a PhD student, first year of study, at the Bucharest University of Economic Studies, Finance Doctoral School, and currently he is working on PhD thesis: "Theoretical and empirical approaches on progressive versus proportional taxation dilemma". 